University of Nebraska - Lincoln

DigitalCommons@University of Nebraska - Lincoln

Agronomy \& Horticulture - Faculty Publications

Agronomy and Horticulture Department

$1-1-1998$

\title{
Tiller Demographics and Leaf Area Index of Four Perennial Pasture Grasses
}

Robert B. Mitchell

Texas Tech University, rob.mitchell@ars.usda.gov

Lowell E. Moser

University of Nebraska-Lincoln, Imoser1@unl.edu

Kenneth J. Moore

lowa State University, kjmoore@iastate.edu

Daren D. Redfearn

Louisiana State University Agriculture Center, Southeast Research Station, dredfearn2@unl.edu

Follow this and additional works at: https://digitalcommons.unl.edu/agronomyfacpub

Part of the Plant Sciences Commons

Mitchell, Robert B.; Moser, Lowell E.; Moore, Kenneth J.; and Redfearn, Daren D., "Tiller Demographics and Leaf Area Index of Four Perennial Pasture Grasses" (1998). Agronomy \& Horticulture -- Faculty Publications. 69.

https://digitalcommons.unl.edu/agronomyfacpub/69

This Article is brought to you for free and open access by the Agronomy and Horticulture Department at DigitalCommons@University of Nebraska - Lincoln. It has been accepted for inclusion in Agronomy \& Horticulture -Faculty Publications by an authorized administrator of DigitalCommons@University of Nebraska - Lincoln. 


\title{
CROPS
}

\section{Tiller Demographics and Leaf Area Index of Four Perennial Pasture Grasses}

\author{
Robert B. Mitchell,* Lowell E. Moser, Kenneth J. Moore, and Daren D. Redfearn
}

\begin{abstract}
Developing grazing systems requires basic information on the growth and development of adapted species. The objective of this field study was to determine seasonal tiller demographics and leaf area index (LAI) of intermediate wheatgrass [Thinopyrum intermedium (Host) Barkw. \& D.R. Dewey], smooth bromegrass (Bromus inermis Leyss.), switchgrass (Panicum virgatum L.), and big bluestem (Andropogon gerardii Vitman) tiller populations. This study was conducted in 1992 and 1993 near Mead, NE, on a silty clay loam soil (Typic Argiudoll) as a randomized complete block. Monocultures were harvested six times each year for tiller demographics. Additionally, mean stage count (MSC), a quantified estimate of tiller population maturity, was determined at each harvest. The LAI was indirectly measured using a canopy analyzer at 7- to 14-d intervals. Tiller density for all species generally declined as MSC increased. Tiller demographics were highly variable by year for intermediate wheatgrass and smooth bromegrass, which indicates that grazing management should be based on current tiller populations. Density of vegetative tillers declined most rapidly for smooth bromegrass, followed by intermediate wheatgrass, switchgrass, and big bluestem. Switchgrass and big bluestem tiller demographics were more uniform and predictable across years than intermediate wheatgrass and smooth bromegrass. The LAI for all species increased as MSC increased. Maximum LAI for intermediate wheatgrass, smooth bromegrass, switchgrass, and big bluestem in 1992 was 4.7, 5.1, 4.9, and 5.8, respectively. Integrating tiller demographics and LAI suggests that initial grazing readiness starts with smooth bromegrass in early spring, followed by intermediate wheatgrass in about 2 wk, switchgrass in late spring, and big bluestem in early summer.
\end{abstract}

$\mathrm{S}$ ELECTION OF SPECIES for complementary grazing systems historically has been based on quantity of forage rather than forage quality. The goal of such systems is to provide an adequate level of quality forage throughout the grazing season. Grazing systems should be based on the supply of available nutrients. Basic information on the growth and developmental morphology of adapted species is required to develop efficient grazing systems. Timing the use of first growth is important to allow for regrowth and optimize season-long nutrient utilization.

Intermediate wheatgrass and smooth bromegrass are introduced perennial cool-season grasses that are well adapted and commonly used for pasture in the central Great Plains. Most perennial cool-season grasses, such

R.B. Mitchell, Dep. of Range, Wildlife, and Fisheries Management, Texas Tech Univ., Lubbock, TX 79409; L.E. Moser, Dep. of Agronomy, Univ. of Nebraska, Lincoln, NE 68583; K.J. Moore, Dep. of Agronomy, Iowa State Univ., Ames, IA 50011; and D.D. Redfearn, Louisiana State Univ. Agric. Center, Southeast Res. Stn., Franklinton, LA 50011. Published as Journal Series no. 11549 of the Agricultural Research Division of the Univ. of Nebraska. Received 25 Sept. 1996. *Corresponding author (c7mrb@ttacs.ttu.edu).

Published in Agron. J. 90:47-53 (1998). as intermediate wheatgrass and smooth bromegrass are photoperiod sensitive (Heide, 1984, 1994). Switchgrass and big bluestem, perennial warm-season grasses native to the central Great Plains, also are photoperiod sensitive (Benedict, 1941). Vegetative growth of all four species is determinate and terminates with inflorescence development (Dahl and Hyder, 1977). Switchgrass and big bluestem have become increasingly important as pasture grasses in the central and eastern United States because of their productivity during the hot summer months, when cool-season grasses are relatively unproductive (Moser and Vogel, 1995). The developmental morphology of these perennial grasses affects forage yield and quality and, hence, management decisions (Moore et al., 1991). Perennial grass tiller populations can be quantified to compare growth and developmental morphology (Moore and Moser, 1995).

Perennation of established grass swards occurs through asexual reproduction of new tillers or rhizomes from axillary buds (Waller et al., 1985). Tiller density is controlled by the rate of recruitment of new tillers and the mortality of existing tillers (Langer et al., 1964; Briske, 1991). Often, there is high tiller natality and high tiller mortality coinciding with flowering in perennial grasses (Matthew et al., 1993). In a smooth bromegrass sward, tiller density was highest in early spring and decreased as spring growth progressed (Krause and Moser, 1980). Tiller recruitment in perennial cool-season grasses such as smooth bromegrass involves at least two tiller generations annually, with tillering episodes occurring in early spring and immediately following anthesis (Lamp, 1952; Krause and Moser, 1980).

Canopy architecture plays an important role in many plant canopy processes and provides information that can be useful to describe interactions between plants and the environment (Welles and Norman, 1991). Canopy architecture affects photosynthesis, quality of forage offered to grazing animals, and animal grazing patterns (Nelson and Moser, 1994). Canopy architectural measurements such as leaf area index (LAI) provide information related to relative light interception, forage productivity, and leaf accessibility to grazing livestock. The objective of this study was to determine the seasonal tiller demographics and changes in LAI of intermediate wheatgrass, smooth bromegrass, switchgrass, and big bluestem tiller populations.

\section{MATERIALS AND METHODS}

This study was conducted in 1992 and 1993 at the University of Nebraska Agricultural Research and Development Center

Abbreviations: DOY, day of the year; GDD, growing degree days; LAI, leaf area index; MSC, mean stage count; TD, tiller density. 
near Mead, NE. Plots were established in the spring of 1991 by seeding $5 \mathrm{~kg}$ of pure live seed ha ${ }^{-1}$ in rows spaced $15 \mathrm{~cm}$ apart on a Sharpsburg silty clay loam soil (fine, smectitic, mesic Typic Argiudoll). Treatments were assigned to experimental units using a randomized complete block design with a splitplot arrangement and three replicates. Species were whole plots $(5$ by $10 \mathrm{~m})$ and years were subplots $(5$ by $5 \mathrm{~m}$ ). Vegetation on the plots to be harvested in 1992 remained undisturbed throughout the 1991 growing season. In 1992, one half of each whole plot was randomly selected and divided into six subplots ( 1.7 by $2.5 \mathrm{~m}$ ) randomly assigned for each harvest date. Vegetation on the plots to be harvested in 1993 remained undisturbed throughout the 1992 growing season. In 1993, the previously nonharvested portion of each whole plot was divided intc six subplots and randomly assigned for each harvest date. Standing dead material was mowed to a $2-\mathrm{cm}$ stubble height and residue removed prior to initiation of spring growth each year. Fertilizer was applied in late May 1992 and 1993 at $110 \mathrm{~kg}$ $\mathrm{N} \mathrm{ha}^{-1}$. 'Lincoln' smooth bromegrass and 'Slate' intermediate wheatgrass were harvested on 13 and 27 May, 10 and 24 June, and 8 and 30 July 1992 and 1993. 'Trailblazer' switchgrass and 'Pawnee' big bluestem were harvested on 20 May, 3 and 17 June, 2 and 14 July, and 12 Aug. 1992 and 1993.

Leaf area index for each species was measured on the nonharvested portion of each whole plot on 13, 20, and 27 May; $3,10,18$, and 23 June; and 3 and 10 July 1992 and 13, 20, and 27 May; 3, 10, and 17 June; 15 July; and 16 Aug. 1993. The LAI was indirectly measured using the LAI-2000 (LI-COR, Lincoln, NE, USA) ${ }^{1}$ canopy analyzer fitted with an opaque mask to reduce the field of view to $90^{\circ}$ to block undesirable objects and reduce measurement errors (Welles and Norman, 1991). Each LAI determination consisted of a minimum of 20 below-canopy measurements interspersed with four abovecanopy measurements taken within $2 \mathrm{~m}$ of the whole plot perimeter. Measurements were taken at dawn, or within the first $4 \mathrm{~h}$ of daylight, when the sun was totally obscured by clouds.

Tillers used for morphological classification were handclipped at ground level from $0.09-\mathrm{m}^{2}$ quadrats randomly located within each subplot. Tillers were morphologically classified using the system described by Moore et al. (1991). Mean stage count (MSC) and tiller density were determined for each species at each harvest date. Individual tillers were not followed during the study. Vegetative tillers present late in the sampling period were presumed to be newly recruited tillers. Accumulated growing degree days (GDD) for the coolseason grasses was calculated as the sum of the difference between the mean daily temperature and a base temperature of $4^{\circ} \mathrm{C}$ after 1 January. Accumulated GDD for the warmseason grasses was calculated as the sum of the difference between the mean daily temperature and a base temperature of $10^{\circ} \mathrm{C}$ after 1 January.

Tiller data were analyzed using analysis of variance procedures and LAI data were analyzed using regression procedures (SAS, 1985). A combined analysis of variance was conducted across years for tiller density, demographics, and LAI. Regression analyses were conducted across years for each species for LAI on day of the year (DOY), LAI on GDD, and LAI on MSC.

\section{RESULTS AND DISCUSSION}

Stand establishment was excellent for all species at the conclusion of the 1991 growing season. Total precipi-

${ }^{1}$ Use of product names does not imply endorsement by the University of Nebraska.
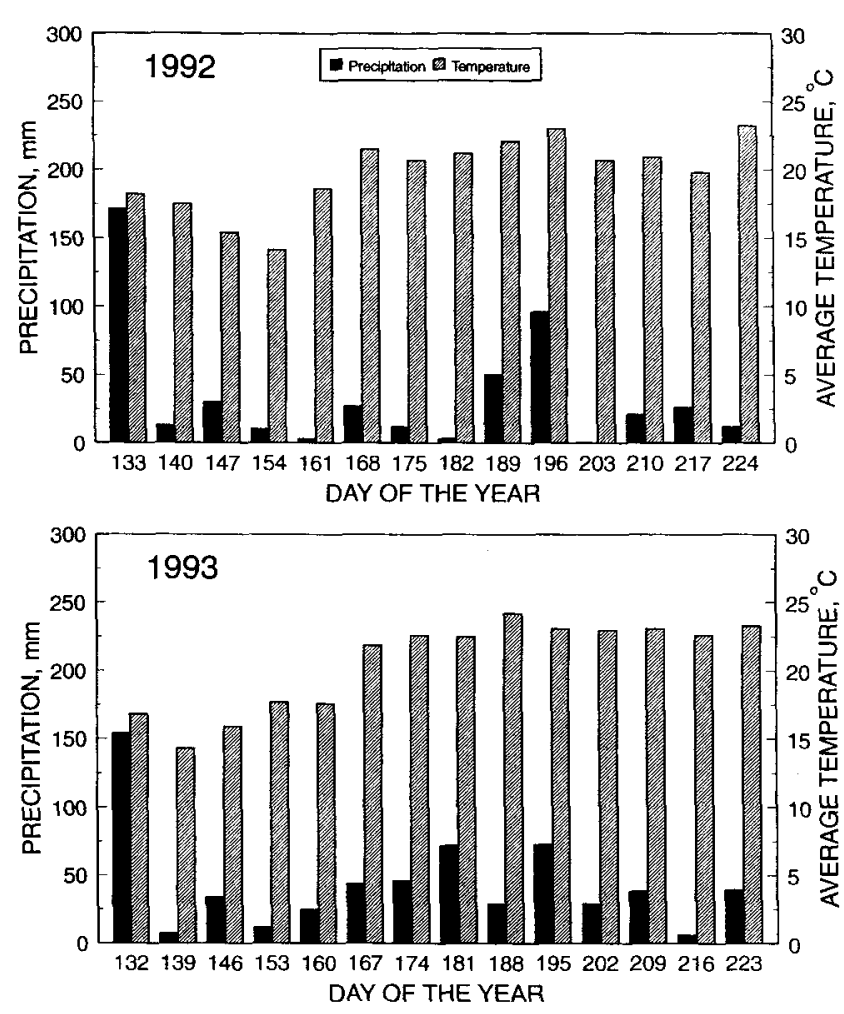

Fig. 1. Precipitation and average daily temperature for plots near Mead, NE, during the 1992 and 1993 growing seasons. Bars indicate total precipitation and average daily temperature since the previously noted day of the year (DOY), except that bars for DOY 133 in 1992 and DOY 132 in 1993 indicate accumulated precipitation from DOY 1.

tation was higher in 1993 than in 1992. The study site received 171 and $154 \mathrm{~mm}$ of precipitation from 1 January to initial harvest in 1992 and 1993, respectively (Fig. 1). Throughout the sampling period, an additional 303 and $453 \mathrm{~mm}$ of precipitation was received in 1992 and 1993 , respectively. Long-term average annual precipitation at Mead is $680 \mathrm{~mm}$ with $500 \mathrm{~mm}$ occurring between 1 April and 1 October. Annual precipitation was near the longterm average in 1992, exceeded the long-term average in 1993, and totaled 658 and $859 \mathrm{~mm}$, respectively. Tiller density at the first harvest date was greater $(P \leq 0.0117)$ in 1993 than 1992 for all species.

\section{Tiller Demographics}

\section{Cool-Season Grasses}

Tiller density of intermediate wheatgrass and smooth bromegrass differed $(P=0.05)$ by species and harvest date in 1992 and 1993. Intermediate wheatgrass tiller density was relatively stable during 1992, but was highly variable in 1993 (Fig. 2). Average intermediate wheatgrass tiller density throughout the sampling period was 1381 and 1954 tillers $\mathrm{m}^{-2}$ in 1992 and 1993 , respectively. There was a general inverse relationship (tiller density (TD) $=2961-547$ (MSC); $r^{2}=0.30$ ) between $\mathrm{MSC}$ and tiller density for intermediate wheatgrass.

Tiller demographics of intermediate wheatgrass differed $(P \leq 0.087)$ in 1992 and 1993, except for the reproductive stage ( $P=0.3633$ ) (Fig. 2). At least 93\% 

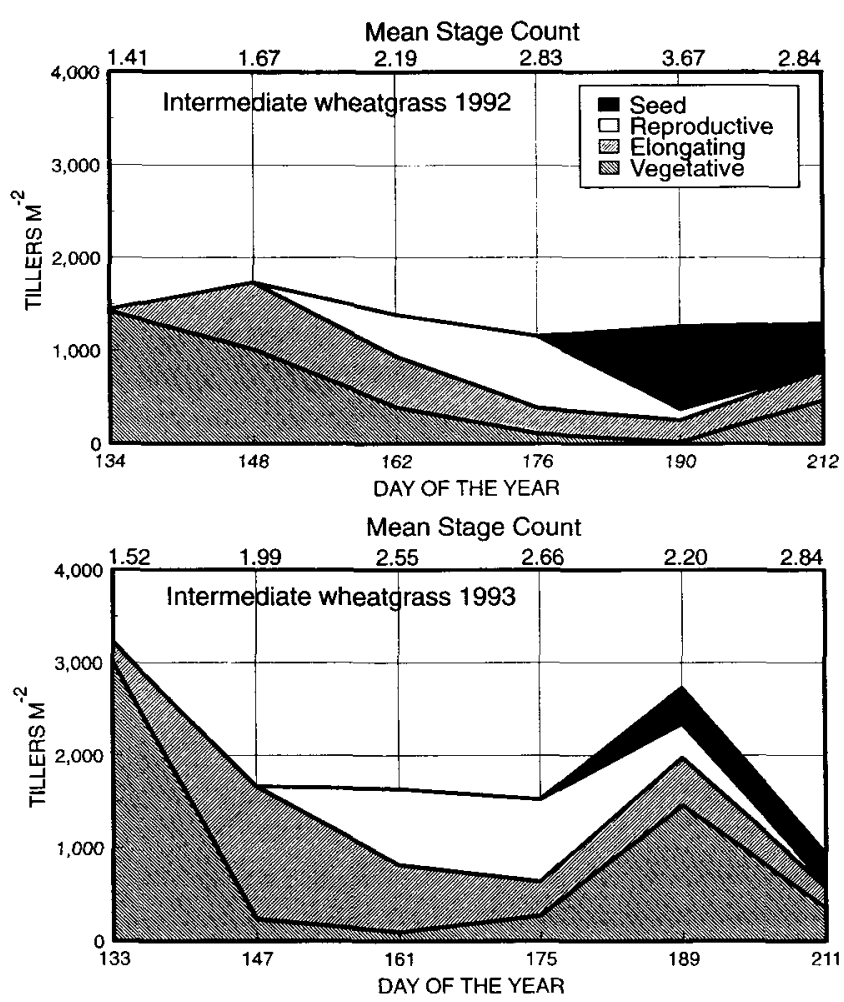

Fig. 2. Number of tillers $\mathrm{m}^{-2}$ in vegetative, elongating, reproductive, and seed ripening growth stages for intermediate wheatgrass grown near Mead, NE, during 1992 and 1993. Mean stage count is included to describe the developmental morphology of the tiller population.

of intermediate wheatgrass tillers were vegetative at the first harvest dates in 1992 and 1993. In 1992, 71\% of the tillers present on DOY 190 were in the seed ripening stage; in 1993 , only $14 \%$ of the tillers present on DOY 189 were in the seed ripening stage. The low percentage of tillers reaching the seed ripening stages on DOY 189 in 1993 was predominantly due to an increase in tiller number that occurred between DOY 175 and 189 that reduced the percentage of seed ripening tillers in the population. No increase in tiller number was observed during this same period in 1992, presumably due to inadequate precipitation (Fig. 1). The increase in tiller number that occurred between DOY 175 and 189 in 1993 (Fig. 2) was probably a response to precipitation. About $50 \mathrm{~mm}$ of precipitation was received between DOY 176 and 190 in 1992; in 1993, more than $100 \mathrm{~mm}$ of precipitation was received between DOY 175 and 189 (Fig. 1). These results are similar to the trends described by Moore and Moser (1995), who reported that intermediate wheatgrass tiller density decreased as MSC increased. However, they determined that the vegetative phase ceased by DOY 156, but they ended their harvest on DOY 190 . In the current study, harvest continued for another $20 \mathrm{~d}$, and an additional tiller generation was observed during both years.

Smooth bromegrass tiller density and demographics differed ( $P \leq 0.0013$ ) during 1992 and 1993 (Fig. 3). The distinct difference in population structure between first harvest dates in 1992 and 1993 is probably due to cooler spring temperatures in 1993 that accumulated
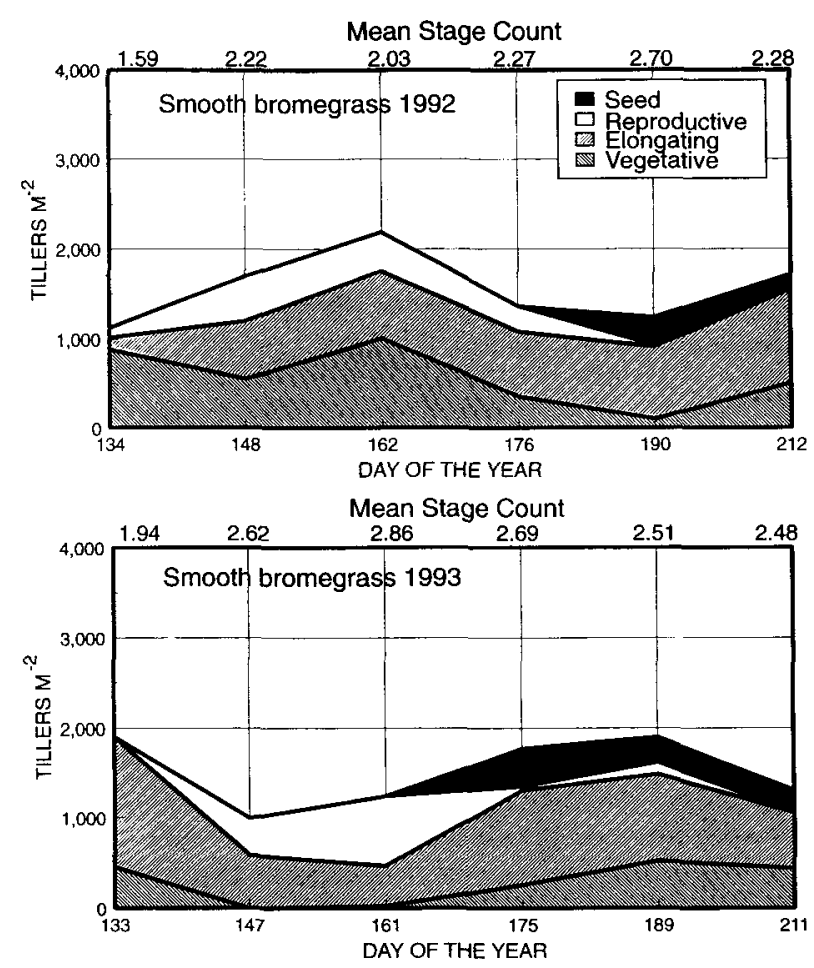

Fig. 3. Number of tillers $\mathrm{m}^{-2}$ in vegetative, elongating, reproductive, and seed ripening growth stages for smooth bromegrass grown near Mead, NE, during 1992 and 1993. Mean stage count is included to describe the developmental morphology of the tiller population.

$40 \%$ fewer GDD by DOY 133 . Average tiller density during the harvest period was 1554 and $1521{\text { tillers } \mathrm{m}^{-2}}^{-2}$ in 1992 and 1993, respectively. Large fluctuations in tiller demographics due to natality and mortality occurred in 1992 and 1993. However, there was a general inverse relationship $\left[\mathrm{TD}=3535-810(\mathrm{MSC}) ; r^{2}=0.42\right]$ between MSC and tiller density for smooth bromegrass. Krause and Moser (1980) reported that tiller density in a smooth bromegrass sward was highest in early spring and decreased as spring growth progressed. At the first harvest in $1992,77 \%$ of smooth bromegrass tillers were vegettative, $14 \%$ elongating, and $9 \%$ reproductive; in 1993 , only $23 \%$ were vegetative and $77 \%$ were elongating. In 1992, $24 \%$ of the tillers present on DOY 190 were in the seed ripening stage; in $1993,15 \%$ of the tillers present on DOY 189 were in the seed ripening stage.

Lamp (1952) and Krause and Moser (1980) reported that tiller recruitment in smooth bromegrass involves two tiller generations annually, with tillering episodes occurring in early spring and immediately following anthesis. In our study, however, three distinct periods of increase in tiller numbers were observed for smooth bromegrass in 1992 (Fig. 3). The first period of tiller increase occurred in early spring (emergence), the second following elongation (DOY 148), and the third following the conclusion of the reproductive stage (DOY 190). In 1993, at least two periods of tiller recruitment were observed. The first occurred in early spring (emergence) and the second between DOY 161 and 189.

The lower MSC for smooth bromegrass compared 
with intermediate wheatgrass late in the growing season indicates that a smaller proportion of smooth bromegrass tillers advanced to reproductive and seed ripening stages (Fig. 2 and 3). Large differences in tiller demographics resulted in small differences in MSC. For example, intermediate wheatgrass on DOY 175 in $1993 \mathrm{had}$ a MSC of 2.66, with few vegetative tillers (Fig. 2). However, between DOY 175 and 189 in 1993, an increase in tiller number occurred, the sward became dominated by vegetative tillers, and the MSC dropped to 2.20 . The increase in intermediate wheatgrass and smooth bromegrass tiller density from DOY 175 to 189 in 1993 probably resulted from greater precipitation during the weeks preceding DOY 189 (Fig. 1). From DOY 162 to 190 in 1992, potential evapotranspiration exceeded precipitation by $159 \mathrm{~mm}$; from DOY 161 to 189 in 1993, precipitation exceeded potential evapotranspiration by $27 \mathrm{~mm}$.

Most temperate grass species must be vernalized for floral initiation to occur (Heide, 1984). The number of intermediate wheatgrass and smooth bromegrass vegetative tillers present on DOY 212 in 1992 was similar to the number of tillers that reached the seed ripening stage in 1993. Vegetative tillers present the previous fall probably were tillers with the potential to develop to maturity in the subsequent growing season, depending on mortality induced by environmental stresses (Moore and Moser, 1995).

The variability in intermediate wheatgrass and smooth bromegrass tiller demographics across years illustrates that harvest management decisions should be based on plant morphology. In 1992, numerous vegetative tillers of both species were present through DOY
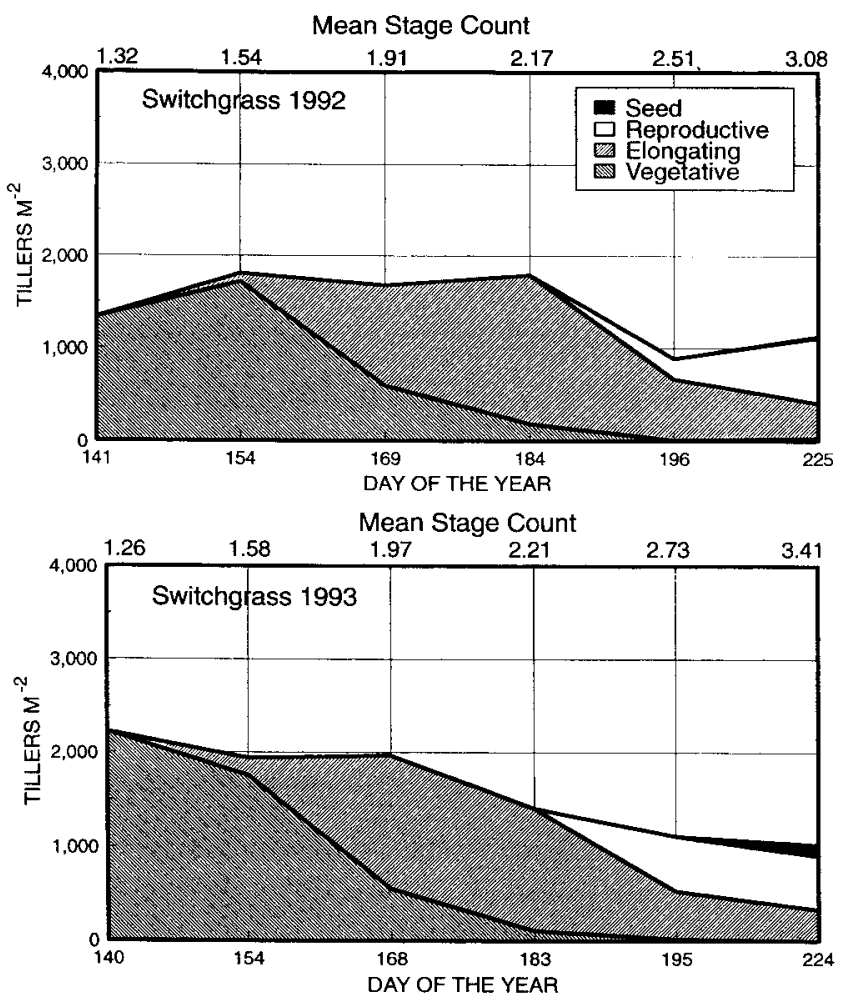

Fig. 4. Number of tillers $\mathrm{m}^{-2}$ in vegetative, elongating, reproductive, and seed ripening growth stages for switchgrass grown near Mead, NE, during 1992 and 1993. Mean stage count is included to describe the developmental morphology of the tiller population.
162 (Fig. 2 and 3). The large proportion of vegetative tillers indicates that grazing livestock would have the opportunity to select for higher quality forage from less mature tillers. Additionally, tiller regrowth following grazing would be maximized. Most defoliated tillers would be in the vegetative or early elongating stages, and a majority of the tiller shoot apices would remain intact following defoliation. The most rapid regrowth occurs from defoliated tillers with an intact growing point (Waller et al., 1985). During 1993, however, the proportion of vegetative tillers in the swards of both species dropped rapidly between DOY 133 and 147, and few vegetative tillers were present on DOY 147. If close grazing had occurred between DOY 147 and 175 in 1993, tillers with elevated shoot apices would likely have been defoliated and regrowth potential would have been slow (Waller et al., 1985). However, a large proportion of vegetative tillers were present after DOY 175, which suggests that grazing animals can select less mature and therefore higher quality tillers in early summer if precipitation is adequate. Additionally, when large proportions of tillers are in the elongating and reproductive stages, grazing may be used to open the canopy and encourage recruitment of new tillers if soil water is adequate.

\section{Warm-Season Grasses}

Tiller density and demographics of switchgrass and big bluestem were more uniform and predictable across years than intermediate wheatgrass and smooth bromegrass. Tiller density of big bluestem was higher than
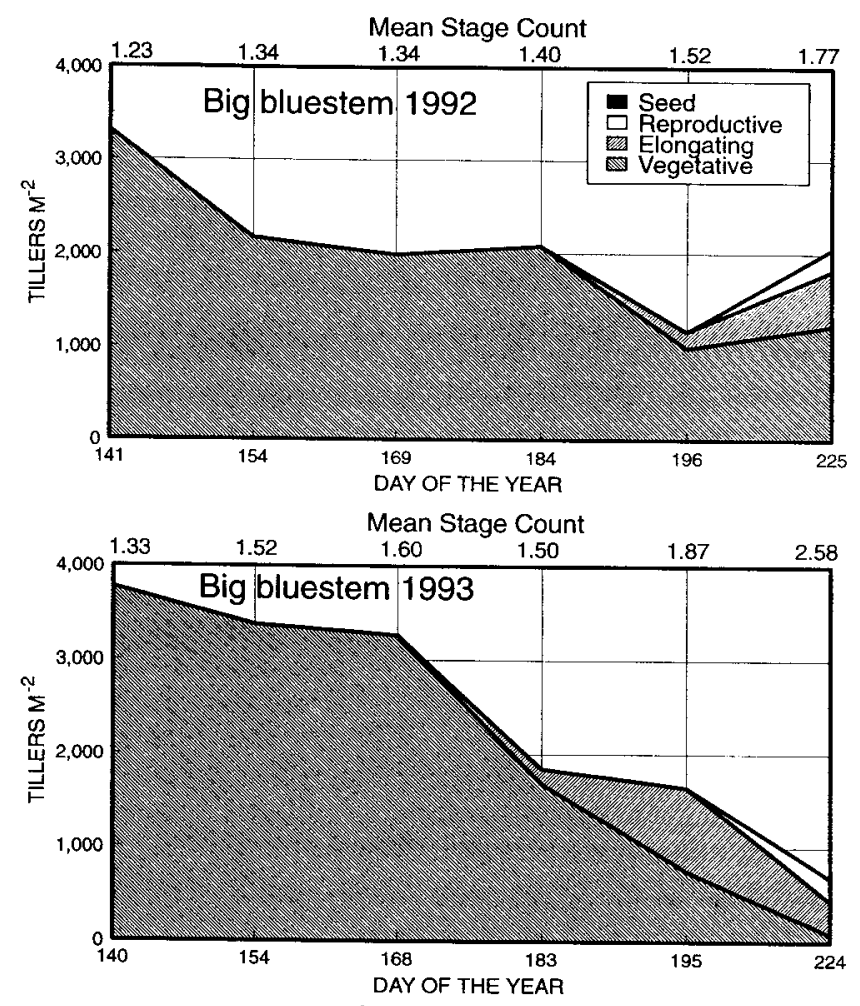

Fig. 5. Number of tillers $\mathrm{m}^{-2}$ in vegetative, elongating, reproductive, and seed ripening growth stages for big bluestem grown near Mead, NE, during 1992 and 1993. Mean stage count is included to describe the developmental morphology of the tiller population. 
switchgrass $(P=0.09)$ during 1992 and 1993, except on DOY 224 in 1993. There was a general inverse relationship [TD $\left.=2545-476(\mathrm{MSC}) ; r^{2}=0.57\right]$ between MSC and tiller density for switchgrass. Switchgrass tiller density in 1992 did not decline until DOY 184, but tiller density in 1993 declined linearly throughout the growing season (Fig. 4). Switchgrass vegetative tiller density declined by an average of 41 tillers $\mathrm{d}^{-1}$ from DOY 154 to 196 in 1992 , and by an average of 42 tillers $d^{-1}$ from DOY 154 to 195 in 1993. Average switchgrass tiller density during the harvest period was 1439 and 1612 tillers $\mathrm{m}^{-2}$ in 1992 and 1993, respectively. Switchgrass tiller density at the conclusion of 1992 and 1993 harvests was similar.

Large changes in switchgrass tiller demographics resulted in larger changes in MSC than did tiller demographic changes in the cool-season grasses. All switchgrass tillers were vegetative at the first harvest in 1992 and 1993, and MSC was approximately 1.3. However, in a 4-wk period, MSC increased to about 1.9 and at least $65 \%$ of the tillers were elongating. No vegetative tillers were present at the final harvest in 1992 or 1993. In 1992 , only $1 \%$ of the tillers advanced to the seed ripening stage; $12 \%$ of the tillers advanced in 1993 .

The large proportion of elongating, reproductive, and seed ripening tillers after DOY 169 and 168 in 1992 and 1993, respectively, reinforces the importance of grazing switchgrass in late spring and early summer (Fig. 4). Improper timing of switchgrass grazing results in low animal performance and may be detrimental to stand persistence (Anderson and Matches, 1983). Grazing on switchgrass should begin when a large proportion of
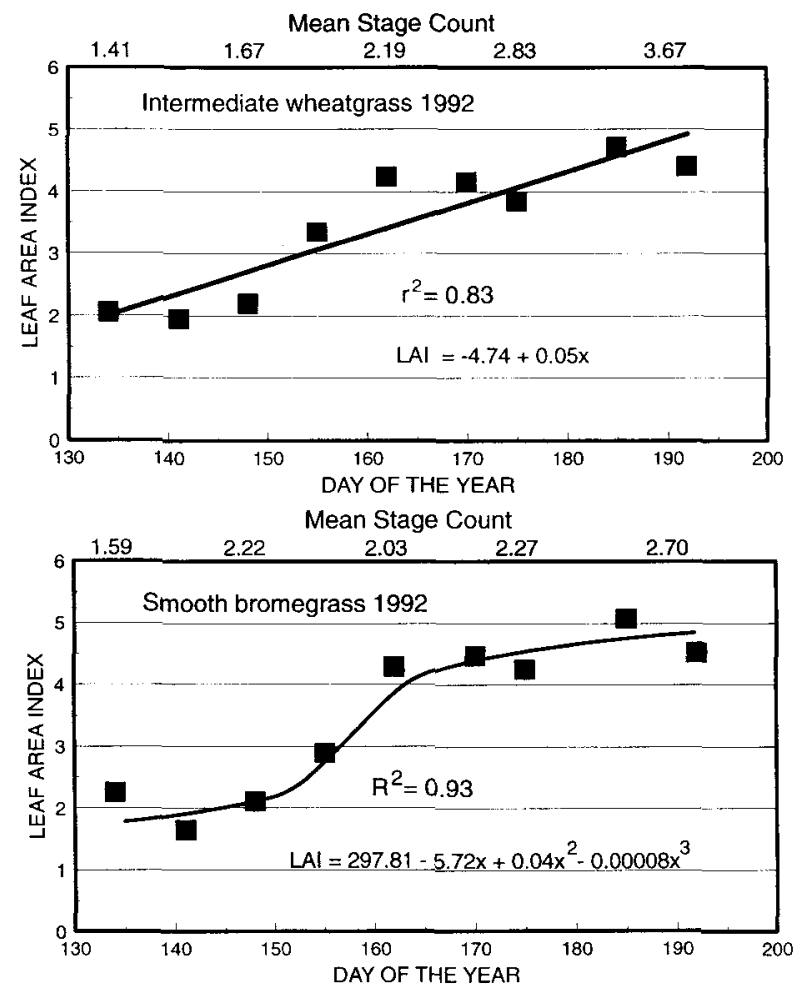

Fig. 6. Leaf area index for intermediate wheatgrass and smooth bromegrass grown near Mead, $\mathbf{N E}$, during the 1992 growing season. Mean stage count is included to describe the developmental morphology of the tiller population. tillers are vegetative (DOY 154) to maximize tiller regrowth and livestock utilization. If switchgrass grazing was delayed until DOY 168, livestock would still have the opportunity to selectively graze a limited number of vegetative tillers. However, regrowth from most elongated tillers would be limited following defoliation. If grazing was delayed until after DOY 183, at least $90 \%$ of tillers presented to the grazing animal have elongated, thereby exposing the apical meristem to removal by grazing and potentially decreasing regrowth and plant vigor the following spring (Waller et al., 1985).

Big bluestem tiller density generally declined as the growing season progressed (Fig. 5), and there was a general inverse relationship [TD $=4845-1620$ (MSC); $r^{2}=0.38$ ] between MSC and tiller density for big bluestem. Average big bluestem tiller density across harvest dates was 2129 and 2430 tillers $\mathrm{m}^{-2}$ in 1992 and 1993, respectively. Big bluestem tiller mortality averaged 47 and 18 tillers $\mathrm{m}^{-2} \mathrm{~d}^{-1}$ for the first 4 wk of 1992 and 1993, respectively. As MSC increased, tiller density decreased except at the final harvest in 1992. In 1993, big bluestem tiller density decreased throughout the growing season.

All tillers were vegetative at the first four harvests in 1992 and the first three harvests in 1993. Due to the early conclusion of sampling, few big bluestem tillers reached the reproductive stage and no big bluestem tillers reached the seed ripening stage by the end of sampling in 1992 and 1993. The low MSC for big bluestem throughout the growing season reflected the low proportion of tillers reaching reproductive and seed ripening stages.

Big bluestem matures later in the growing season than

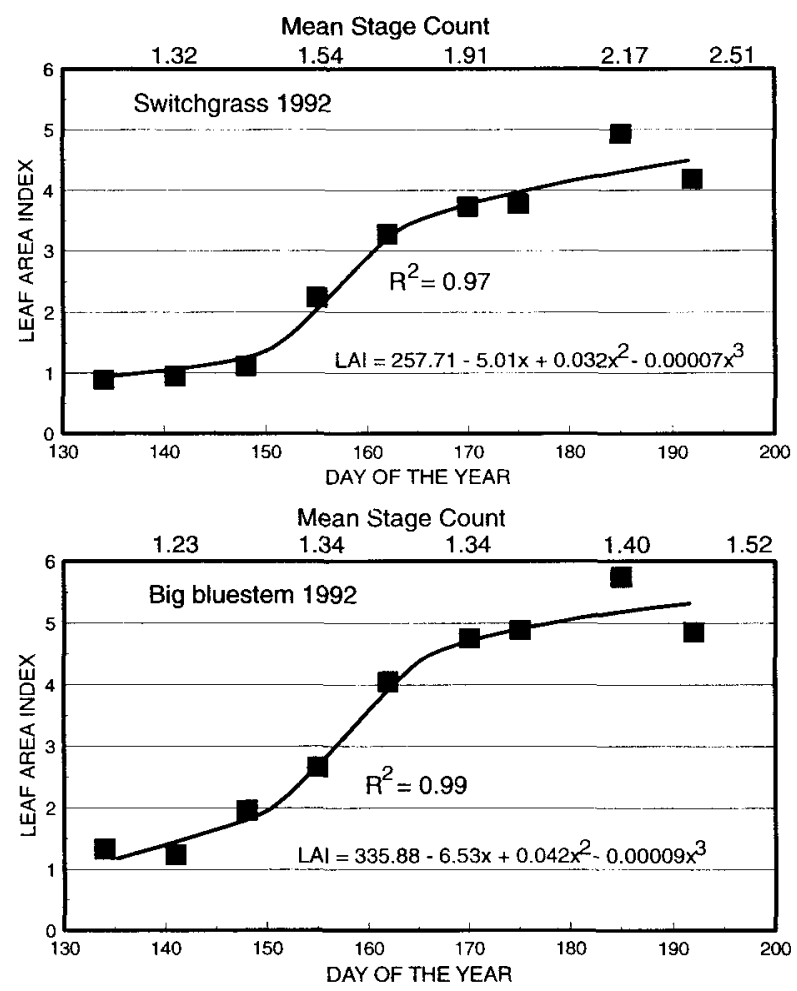

Fig. 7. Leaf area index for switchgrass and big bluestem grown nea Mead, NE, during the 1992 growing season. Mean stage count is included to describe the developmental morphology of the tiller population. 
$(P=0.2207)$. A maximum LAI of 4.9 was reached by switchgrass and 5.8 by big bluestem on DOY 185 . In 1993, switchgrass and big bluestem LAI were significantly higher $(P=0.006)$ throughout the sampling period than in 1992 (data not shown). A maximum LAI of 7.7 was reached by switchgrass on DOY 228 and 8.0 by big bluestem on DOY 168 in 1993. The 1992 results were similar to those of Redfearn et al. (1997), who reported a maximum LAI of 5.5 for tiller populations of eight switchgrass genotypes. The higher maximum LAI in 1993 was probably due to higher precipitation in 1993. The higher LAI for big bluestem probably occurred in response to the high proportion of vegetative tillers present throughout the growing season, which was also reflected in the low MSC for big bluestem. At least $95 \%$ of the variability in switchgrass LAI was explained by DOY in 1992 and 1993 (Table 1). Switchgrass LAI was better predicted by MSC in 1992 and 1993 than was big bluestem LAI. Day of the year accounted for 99 and $84 \%$ of the variability in big bluestem LAI in 1992 and 1993, respectively. Strong relationships between LAI and DOY for switchgrass and big bluestem illustrate their strong photoperiod sensitivity.

\section{CONCLUSIONS}

Yearly variability for intermediate wheatgrass and smooth bromegrass tiller demographics and inconsistent predictability of LAI demonstrates how grazing management should be based on current tiller populations at several periods during the growing season and not on DOY. Although these species are photoperiod sensitive, uniform tiller advancement toward maturity within a species was not observed. Management of vegetative tillers is crucial in first growth. Vegetative tillers declined most rapidly for smooth bromegrass, followed by intermediate wheatgrass, switchgrass, and big bluestem. Integrating tiller demographics and LAI suggests that initial grazing readiness starts with smooth bromegrass in early spring, followed by intermediate wheatgrass in about $2 \mathrm{wk}$, switchgrass in late spring, followed by big bluestem in about 2 wk.

\section{REFERENCES}

Anderson, B., and A.G. Matches. 1983. Forage yield, quality, and persistence of switchgrass and caucasian bluestem. Agron. J. 75: 119-124.
Benedict, H.M. 1941. Effect of day length and temperature on the flowering and growth of four species of grasses. J. Agric. Res. 61:661-672.

Briske, D.D. 1991. Developmental morphology and physiology of grasses. p. 85-108. In R.K. Heitschmidt and J.W. Stuth (ed.) Grazing management: An ecological perspective. Timber Press, Portland, OR

Dahl, B.E., and D.N. Hyder. 1977. Developmental morphology and management implications. p. 257-290. In R.E. Sosebee (ed.) Rangeland plant physiology. Soc. for Range Manage., Denver, CO.

Engel, R.K., L.E. Moser, J. Stubbendieck, and S.R. Lowry. 1987. Yield accumulation, leaf area index, and light interception of smooth bromegrass. Crop Sci. 27:316-321.

Heide, O.M. 1984. Flowering requirements in Bromus inermis, a shortlong-day plant. Physiol. Plant. 62:59-64.

Heide, O.M. 1994. Control of flowering and reproduction in temperate grasses. New Phytol. 128:347-362.

Knapp, A.K. 1984. Post-burn differences in solar radiation, leaf temperature and water stress influencing production in a lowland tallgrass prairie. Am. J. Bot. 71:220-227.

Krause, J.W., and L.E. Moser. 1980. Tillering in irrigated smooth bromegrass (Bromus inermis Leyss.) as affected by elongated tiller removal. p. 189-191. In E. Wojahn and H. Thons (ed.) Proc. Int. Grassl. Congr., 13th Leipzig, GDR. 18-27 May 1977. AkademieVerlag, [East] Berlin.

Lamp, H.F. 1952. Reproductive activity in Bromus inermis in relation to phases of tiller development. Bot. Gaz. (Chicago) 113:413-438.

Langer, R.H.M., S.M. Ryle, and O.R. Jewiss. 1964. The changing plant and tiller populations of timothy and meadow fescue swards: I. Plant survival and the pattern of tillering. J. Appl. Ecol. 1:197-208.

Masters, R.A., R.B. Mitchell, K.P. Vogel, and S.S. Waller. 1993. Influence of improvement practices on big bluestem and indiangrass seed production in tallgrass prairies. J. Range Manage. 46:183-188.

Matthew, C., C.K. Black, and B.M. Butler. 1993. Tiller dynamics of perennation in three herbage grasses. p. 141-143. In M.J. Baker et al. (ed.) Proc. Int. Grassl. Congr., 17th, Palmerston North, NZ. 8-21 Feb. 1993. NZ Grassl. Assn., Palmerston North.

Moorè, K.J., and L.E. Moser. 1995. Quantifying developmental morphology of perennial grasses. Crop Sci. 35:37-43.

Moore, K.J., L.E. Moser, K.P. Vogel, S.S. Waller, B.E. Johnson, and J.F. Pedersen. 1991. Describing and quantifying growth stages of perennial forage grasses. Agron. J. 83:1073-1077.

Moser, L.E., and K.P. Vogel. 1995. Switchgrass, big bluestem, and indiangrass. p. 409-420. In R.F Barnes et al. (ed.) Forages: An introduction to grassland agriculture. 5th ed. Iowa State Univ. Press, Ames.

Nelson, C.J., and L.E. Moser. 1994. Plant factors affecting forage quality. p. 115-154. In G.C. Fahey, Jr., et al. (ed.) Forage quality, evaluation, and utilization. ASA, CSSA, and SSSA, Madison. WI

Redfearn, D.D., K.J. Moore, K.P. Vogel, S.S. Waller, and R.B. Mitchell. 1997. Canopy architecture and morphology of switchgrass populations differing in forage yield. Agron. J. 89:262-269.

SAS Institute. 1985. SAS users guide: Statistics. SAS Inst., Cary, NC

Waller, S.S., L.E. Moser, and P.E. Reece. 1985. Understanding grass growth: The key to profitable livestock production. Trabon Printing Co., Kansas City, MO.

Welles, J.M., and J.M. Norman. 1991. Instrument for indirect measurement of canopy architecture. Agron. J. 83:818-825. 